\title{
Investigating Economic Factors of Sustainability in European Smart Cities
}

\author{
Ana Iolanda Vodă ${ }^{1}$, Laura-Diana Radu ${ }^{2}$
}

\begin{abstract}
Smart city is a complex system which faces multiple challenges to support a sustainable socioeconomic development and improving the quality of living. Building smart cities is a challenge and an imperative solution for optimizing resources availability and distribution processes in the context of massive urbanization. Although, many aspects shape the development of smart cities, the study aims to examine the importance of research and development (R\&D) investments, the patent applications, employed information and communication technology (ICT) specialists, gross domestic product (GDP) and poverty reduction in making cities 'smart'. According to our research objective and developed hypothesis, several data analysis have been used: Principal Component Analysis (PCA), Pearson correlation coefficient and Hierarchical clustering tested on 26 European Member states. Our results show that all the above elements are imperative in supporting a long-term city growth and development.
\end{abstract}

Keywords: Smart Cities, Patent Applications, Employed ICT Specialists, R\&D Investments, GDP, Poverty Rate

\section{Introduction}

Smart city is a complex environment that integrates a wide variety of technologies and supports those innovations capable of delivering sustainable socioeconomic development of cities. The concept was first used in the early 1990s to indicate how urban development integrated technological evolution, innovation and globalization [10]. Over time, several phrases have been used for this new type of city, such as "intelligent city", "city of knowledge", "digital city" or "ubiquitous city" [1, 17]. Smart cities, through developed functionalities and characteristics, are trying to offer solutions for the rapid growth of the population density inside urban environments. In the United Nations report, it is estimated that $60 \%$ of the world's population will live in the city by 2050, which represent an increase from 30\% in 1950 and 54\% in 2014 [31]. This brings new challenges for local and national governmental organizations that need to identify fast and intelligent solutions to address air pollution, urban agglomerations, waste management and population health. Smart cities could bring such solutions. It integrates tangible and intangible assets of cities such as urban mobility, energy management, waste management, water management and e-governance into a unique global concept [16]. The development of ICT and Internet of Things (IoT) solutions has made possible the unification of all information subsystems that manage these components [26]. The goal is to improve the quality of life for citizens in the form of enhancing liveability, sustainability, and efficiency [9]. In smart cities ICT is used to augment performance,

${ }^{1}$ Department of Interdisciplinary Research - Humanities and Social Sciences, "Alexandru Ioan Cuza" University of Iasi, Romania

2Department of Research, Faculty Economics and Business Administration, "Alexandru Ioan Cuza" University of Iasi, Romania 
quality and interactivity of services. The billions of sensors integrated with real-time monitoring systems can reduce resource consumption and can improve the contact between citizens and government. This will implicitly contribute to cost reductions and sustainable development of cities. According to the European Commission, there are three main priorities for the future cohesion policy after 2013 [28]:

- the competitiveness in research, innovation, and upgrading of skills to promote the knowledge economy;

- the active labour market policy to sustain employment, strengthen social cohesion and reduce the risk of poverty;

- the sustainable development to reduce greenhouse gases emissions and improve the energy efficiency of urban infrastructure.

These priorities should constitute a guide for city officials in developing growth strategies. On the other hand, smart city implementation is closely linked to the standard of living and the level of education. The concept involves citizens' access to digital technologies and the acquisition of the necessary knowledge to use them. According to Schaffers et al. [28] the subsequent elements influence cities and urban development and can help to achieve the status of smart cities: the actors, the priorities, the resources and the policies (Figure 1).

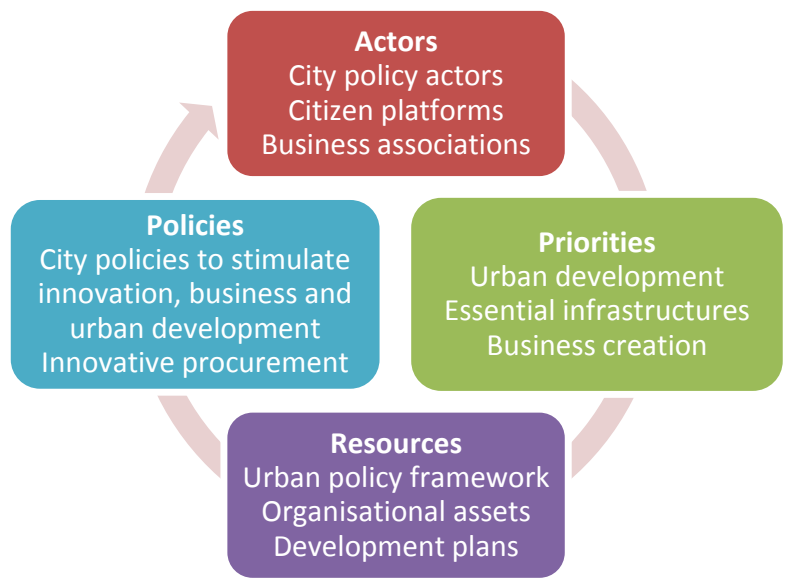

Figure 1. The landscape of the city development (authors' representation based on [28])

As we can see, there are many aspects that shape the development of smart cities, such as innovation capacity, ICT development and adoption, living standards, preparedness of residents, and last but not least, the willingness to invest in this concept.

This study aims to examine the importance of R\&D investments, patent applications, employed ICT specialists, GDP, and poverty reduction in making cities 'smarter'. The rest of this paper is organized as follows. In the next section, the definition and current status with some characteristics of the smart city are given in brief. Then, in the methodology and results sections, several data analysis have been used: Principal Component Analysis (PCA), Pearson correlation coefficient and Hierarchical clustering tested on 26 European Member states. The last section includes the conclusions that we 
have been able to achieve based on analysis results.

\section{Literature Review}

The concept of smart city has become popular and has attracted attention of industry and governments especially in the last two decades. An important moment was its use by important technology companies such as Cisco, Siemens and IBM in 2005 for "the application of complex information systems to integrate the operation of urban infrastructure and services such as buildings, transportation, electrical and water distribution, and public safety" [14]. There is no single, generally-accepted definition. Some definitions have been adopted in both practical and academic use. We selected the most representative and comprehensive found in literature and we present them in the next table.

Table 1. An overview on smart city definitions

\begin{tabular}{|c|c|}
\hline Description & Reference \\
\hline $\begin{array}{l}\text { A city may be called smart "when investments in human and social capital and } \\
\text { traditional (transport) and modern (ICT) communication infrastructure fuel } \\
\text { sustainable economic growth and a high quality of life, with a wise management of } \\
\text { natural resources, through participatory government". }\end{array}$ & [4] \\
\hline $\begin{array}{l}\text { "A city that monitors and integrates conditions of all its critical airport, seaports, } \\
\text { communications, water, power, even major buildings, can better optimize its } \\
\text { resources, plan its preventive maintenance activities, and monitor security aspects } \\
\text { while maximizing services to the citizens". }\end{array}$ & [12] \\
\hline $\begin{array}{l}\text { "A smart city is a well-defined geographical area, in which high technologies such } \\
\text { as ICT, logistic, energy production, and so on, cooperate to create benefits for } \\
\text { citizens in terms of well-being, inclusion and participation, environmental quality, } \\
\text { intelligent development; it is governed by a well-defined pool of subjects, able to } \\
\text { state the rules and policy for the city government and development". }\end{array}$ & [5] \\
\hline $\begin{array}{l}\text { A city "connecting the physical infrastructure, the IT infrastructure, the social } \\
\text { infrastructure, and the business infrastructure to leverage the collective intelligence } \\
\text { of the city". }\end{array}$ & [14] \\
\hline $\begin{array}{l}\text { Smart city "is the combined use of software systems, server infrastructure, } \\
\text { network infrastructure, and client devices (...) to better connect seven critical city } \\
\text { infrastructure components and services: city administration, education, healthcare, } \\
\text { public safety, real estate, transportation, and utilities". }\end{array}$ & [33] \\
\hline
\end{tabular}

Smart cities can also be defined based on six characteristics, developed on a "combination of endowments and activities of self-decisive, independent and aware citizens" [23] and their assigned factors. These characteristics are unified in a complementary way [3, 4]. The six dimensions or characteristics refer to: Smart Economy, Smart Mobility, Smart Environment, Smart People, Smart Living and Smart Governance (Figure 2). By Smart Economy we mean increased productivity and flexibility of the labour market, ICT-enabled innovation, entrepreneurship, trademarks as well as, the integration in the (inter-) national market. Smart Mobility encapsulates ICT supported and integrated transport and logistics systems. The used factors in assessing important aspects of Smart Mobility refer to: local and (inter-) national accessibility, availability of ICT infrastructure 
and sustainable, innovative and safe transport systems. By Smart Environment or 'Attractivity of natural conditions' we mean renewables, pollution control and monitoring, as well as protection and sustainable use of resources. Smart People or 'Social and Human Capital' is used to describe not only the e-skills and the level of qualification of the citizens, but other aspects like the "quality of social interactions regarding integration and public life and the openness towards the 'outer' world" [11]. Smart Living measures various aspects of the best conditions of life, meaning cultural facilities, living with healthy people, utility infrastructure (e. g. water/electricity/heating network), safety housing, etc. Smart Governance comprises various aspects of city governance including services and the efficiently and effectively functioning of the administration. This entails private and public participation in decision making, political strategies and perspective as well as, transparency and open data by using ICT [11, 23, 24, 30].

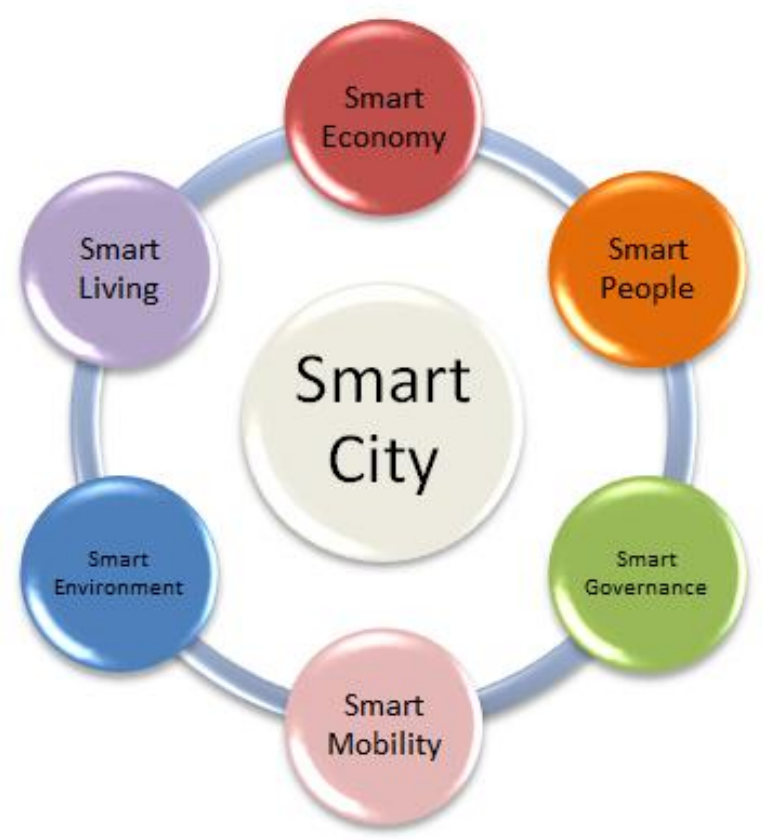

Figure 2. Smart cities characteristics and assigned factors (adapted from [11])

The concept of smart city is conditioned by digital evolution. It involves the use of millions of sensors and devices capable of recording, storing and processing information about the activity of the entire urban community, institutions and citizens, and providing them with real-time updates. According to Harrison et al. [13], smart cities are built on a combination of ideas how ICTs could contribute to increasing the efficiency of cities, improving their functioning and their competitiveness, and finding new solutions for solving problems like poverty, social deprivation, and poor environmental management. These cities also assume both the implementation of ICTs and their use. Increasing the number of employees in this area and the number of jobs with a strong ICT component $[8,15,31]$ are natural results of acquiring intelligent city features. Their citizens need 
smart devices to access the available information and services, as well as the knowledge to use them. On the other hand, in smart cities a significant number of employees work in the field of ICTs. They provide the hardware and software required to ensure the intelligence of cities. In other words, smart cities need smart citizens both as recipients of intelligence and as providers of it.

In many circumstances smart means expensive in the case of smart cities. The unification of all subsystems that manage the information of public and private organizations and the access of citizens to the necessary services and resources require investments in logical and physical infrastructure. The GDP level directly and indirectly influences the implementation of smart city features. It influences R\&D investments, the possibility of transforming inventions into innovations, the ability to adopt ICTs and the poverty rate. A low GDP level makes it impossible for a city to become intelligent. At the same time, the development of smart cities will contribute to GDP growth [21].

The relationship between GDP and R\&D is highlighted by the proposed Europe 2020 strategy to invest 3\% of EU GDP in R\&D or innovation [23]. R\&D investments and willingness to adopt innovations are key elements in implementing the smart city concept. Many of these investments are focused on finding and applying the most effective ways to restore natural balance (waste management, clean energy use, $\mathrm{CO}_{2}$ reduction), because smart cities are sustainable cities or eco-cities. The relationship between smart cities and $\mathrm{R} \& \mathrm{D}$ is bidirectional: $\mathrm{R} \& \mathrm{D}$ results are used to transform cities into smart cities and smart cities initiatives have the potential to support innovative growth and R\&D [23]. They are funded from public and private sources interested in progress. According to Komninos and Sefertzi [19], business and public spending are important indicators for measuring knowledge and innovation institutions in smart cities. Many innovations are the results of the recognized and recorded inventions. The patent applications (per million of population) is a component in measuring the performance of innovations in smart cities $[19,25]$. Investments in R\&D and the development of digital technologies have led to a significant increase in the patents registered by international organizations. Some of them turn into innovations and contribute to increasing the intelligence of cities. Most of them are in the ICT field and in the environmental protection field. Valorisation of inventions leads to increased competitiveness between private organizations that fosters economic growth and supports the adoption of specific smart economy features.

Smart city solutions are expected to fight against poverty [2, 5, 28, 34]. Improving the quality of living is one of the core objectives of smart cities. Jobs creation and GDP growth will favourably contribute to reducing the poverty rate in these cities. European Commission, through Europe 2020 program - a strategy for smart growth, sustainable and inclusive growth had included poverty reduction as a component of inclusive growth [7]. A city with a high poverty rate could not be smart. Smartness means access to digital devices, application and services accessible for the citizen with a reasonable standard of living. Smart city means also smart people and smart people could fight against poverty which offers a significant advantage for improving living conditions. Building smart cities is a challenge and an imperative solution for optimizing resource availability and distribution processes in the context of massive urbanization. 


\section{Methodology and Data}

\subsection{Research Methodology}

Smart cities ranking allows us to compare different characteristics and to identify the strong and weak points of medium-size cities in a comparative way. A wide range of attributes ranging from 'smart economy' to 'smart living' are described in the specialized literature in relation to the term 'Smart City'. This holistic view allows us to encapsulate various aspects necessary to assess a city's performance from a smart city perspective. Although several criteria determine the selection of a smart city, the most important ones during 2013-2014 rankings are: population number (100.000-500.000 to obtain mediumsize cities), knowledge basis (at least one university) and catchment areas with less than 1.5 million. Also, availability and relevancy of the data represented other import selection criteria. The 2015 ranking incorporate some changes when compared to its earlier versions as small adjustments were made to the most important selection criteria: a) in obtaining a medium-size city the number of inhabitants was situated between 300.000 and 1 million; b) the cities must be listed in Urban Audit Database and c) more than 80\% of the indicators data must be available. Thus, the variables standardization remain the same: for each city in order to compare different indicators, the values were standardized with an average ' 0 ' and a standard deviation ' 1 '. The countries number of cities varies each year according to selection criteria and smart city performances [32]. In our analysis we have used the smart cities rankings available in 26 European Countries.

Other indicators used in the analysis are Patent Applications, Employed ICT Specialists, R\&D Investments, GDP and Poverty Rate. Patent applications refers to the number for requesting exclusive rights for an invention, which have been filed through the WIPO administered PCT (Patent Cooperation Treaty). Another important factor is represented by the employment of ICT specialists. In the analysis, employed ICTs are defined as specialized workers who have the capacity to operate, maintain and develop ICT systems. One of the main measures for achieving a smart, sustainable and inclusive growth are higher R\&D investments [7]. Once this condition is fulfilled, it is expected that immediate short-term problems related to the recent financial crises are better managed and countries will be more able to address pressing long-term challenges related to growth, competitiveness and environmental sustainability [18]. R\&D investments include the data from all private and public sectors R\&D performing entities. The last two indicators taken into account were GDP and Poverty Rate. In the analysis we use the logarithmic values of GDP and for Poverty rate - at-risk-of-poverty rate per country for the total population.

Tests and modelling were performed using Statistical Package for Social Science (SPSS) software, SPSS 21.0 (IBM Corporation, Armonk, NY, USA). According to our research several data analysis have been used: Pearson correlation coefficient, Principal Component Analysis (PCA) and Hierarchical clustering.

In this paper we apply correlation analysis in order to observe the interaction between variables and to measure the strength of the relationship between them. The identification of significant correlations are made using Pearson correlation coefficient. To test the significance of the Pearson correlation coefficient we used Student t-test. The hypotheses are: null hypothesis, absence of significant correlation between the variables 
$\left(\mathrm{H}_{0}: \mathrm{p}=0\right)$; alternative hypothesis, which shows that there is a statistical significant relation between the variables $\left(\mathrm{H}_{1}: \mathrm{p} \neq 0\right)$. If the calculated value of statistical $\mathrm{t}$ is higher than the theoretical value then the null hypothesis $\left(\left(\mathrm{H}_{0}: p=0\right)\right.$ is validated. On the contrary if the $\mathrm{F}$ value is smaller then the null hypothesis is rejected and the variables are significantly correlated with the assumed risk.

The intensity and direction of the relationship between the variables included in the analysis is obtained using Principal Components Analysis (PCA). This method allows us graphical representation on a factorial axes system of the relationship between the variables. Hierarchal cluster analysis is also used for exploring similarities between countries.

\subsection{Data collection and sample}

Given the data availability for the smart city rankings, the geographical focus of our study is on 26 European countries namely: Austria, Belgium, Bulgaria, Croatia, Czech Republic, Denmark, Estonia, Finland, France, Greece, Hungary, Ireland, Italy, Latvia, Lithuania, Luxemburg, Netherland, Poland, Portugal, Romania, Slovakia, Slovenia, Spain, Sweden and United Kingdom which gives us a total of 78 cities sample.

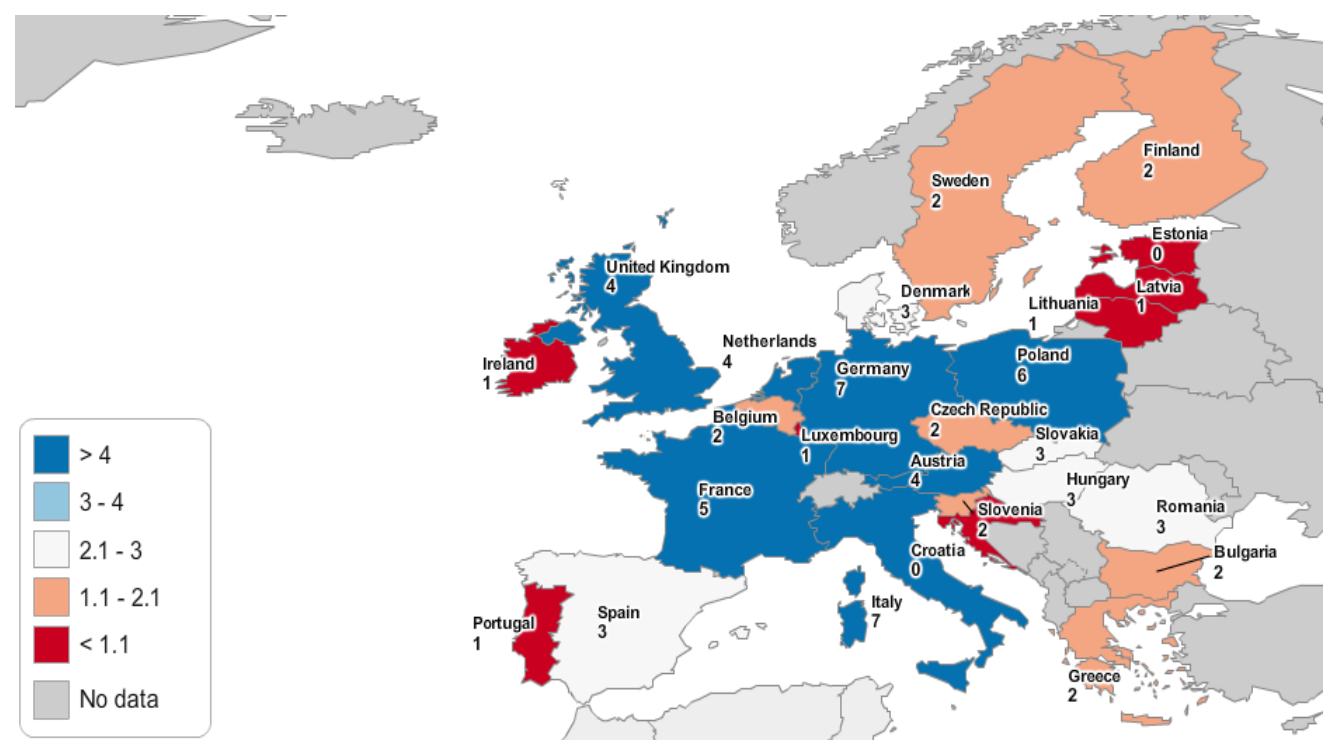

Figure 3. Smart cities, 2013 (Authors' representation based on Smart-cities.eu data [32])

Mapping smart cities across EU-26 shows that these are not evenly distributed (Figure 3 and Figure 4). In 2013, the number of smart cites was situates between " 0 " and " 1 " for countries like Croatia, Estonia, Ireland, Latvia, Lithuania, Luxemburg and Portugal. A higher number were register in Germany (7), Italy (7), Poland (6) and France (5). In all the other countries the number of smart cities was ranging between 2 and 4 . In 2014, the number of smart cities increased in Estonia (from " 0 " to " 1 "), Finland (from " 2 " up to "4"), Spain ("4" instead of “3”) and United Kingdom (from "4" up to "5").

In 2015, the number of smart cities decreased in Austria, Denmark, Finland, Hungary, 
Luxemburg, Netherland, Romania, Slovak Republic and Slovenia. In 2015, the highest number of smart cities were register in Germany (16), Spain (11) France (11) and United Kingdom (10) (Figure 4). Smart cities initiatives are spread across their six characteristics, but Smart Environment and Smart Mobility are in the centre of attention. On the other hand, although Smart Governance projects are particularly seen in older member states like France, Germany, UK and Spain, there are fairy even spread across the region. Moreover, some of smart city characteristics usually occur in combination such as Smart People and Smart Living [23].

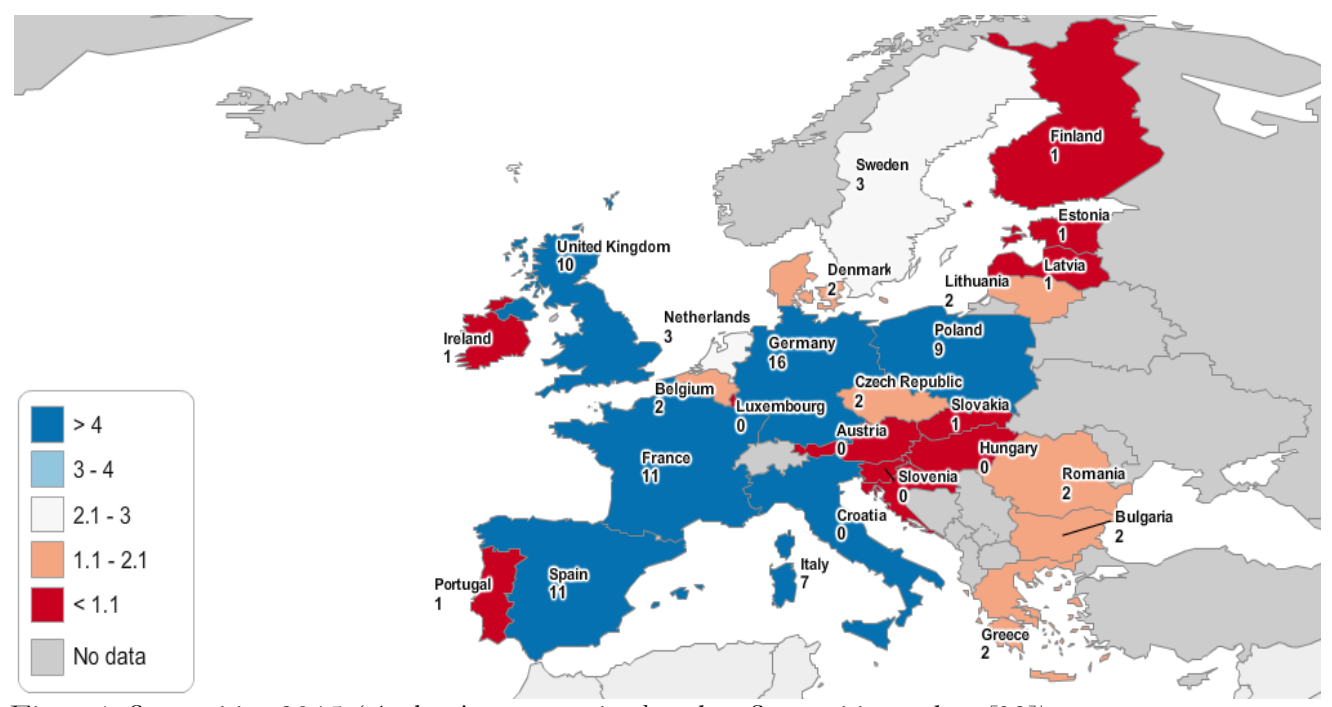

Figure 4. Smart cities, 2015 (Authors' representation based on Smart-cities.eu data [32])

We have collected the data for a three year period: 2013, 2014 and 2015. For smart city rankings we used the data provided by Smart-cities.eu website [32]. For Employed ICT Specialists, R\&D Investments, GDP and Poverty Rate we used Eurostat database [6] and for Patent Application, the one belonging to World Bank [35]. Due to the lack of data for Slovenia regarding the patent applications, only 75 cities sample remained in the analysis, within 25 European Countries.

\section{Results and interpretation}

Table 2 presents the values for Pearson coefficient and significance level associated to the computed value of Student statistic. 
Table 2. Pearson correlations

\begin{tabular}{|c|c|c|c|c|c|c|c|}
\hline & & $\begin{array}{c}\text { Smart } \\
\text { cities rank }\end{array}$ & $\begin{array}{c}\text { Patent } \\
\text { application }\end{array}$ & $\begin{array}{c}\text { Employed } \\
\text { ITCs }\end{array}$ & $\begin{array}{c}\text { Poverty } \\
\text { Rate }\end{array}$ & $\begin{array}{c}\mathrm{R} \& \mathrm{D} \\
\text { Investment }\end{array}$ & GDP \\
\hline $\begin{array}{l}\text { Smart cities } \\
\text { rank }\end{array}$ & \multirow{6}{*}{ 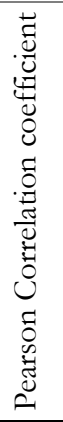 } & 1 & $.673(* * *)$ & $.752(* * *)$ & $-.193(* *)$ & $.185(*)$ & $.471(* * *)$ \\
\hline $\begin{array}{l}\text { Patent } \\
\text { application }\end{array}$ & & $.673(* * *)$ & 1 & $.848(* * *)$ & $-.288(* *)$ & $.313(* * *)$ & $.352(* * *)$ \\
\hline $\begin{array}{l}\text { Employed } \\
\text { ITCs }\end{array}$ & & $.752(* * *)$ & $.848(* * *)$ & 1 & $\begin{array}{c}- \\
.302(* * *)\end{array}$ & $.290(* *)$ & $.499(* * *)$ \\
\hline $\begin{array}{l}\text { Poverty } \\
\text { Rate }\end{array}$ & & $-.193(* *)$ & $-.288(* *)$ & $-.302(* * *)$ & 1 & $-.750(* * *)$ & $-.134(*)$ \\
\hline $\begin{array}{l}\text { Investment } \\
\text { R\&D }\end{array}$ & & $.185(*)$ & $.313(* * *)$ & $.290(* *)$ & $\begin{array}{c}- \\
.750(* * *) \\
\end{array}$ & 1 & $.258(* *)$ \\
\hline GDP & & $.471(* * *)$ & $.352(* * *)$ & $.499(* * *)$ & $-.134(*)$ & $.258(* *)$ & 1 \\
\hline
\end{tabular}

Our findings showed with a probability of $95 \%$, the existence of a positive and strong relationship between the variables describing smart city rankings, patent applications and employed ITC specialists, with a Person Coefficient values of 0.673 and 0.752 respectively. Also, significant and positive associations have been found between smart city ranking, investment in R\&D and GDP. At the same time, we notice a negative correlating between the rate of poverty and the smart city rank.

In order to highlight the intensity and direction of the relationship between the variables included in the analysis we used Principal Components Analysis (PCA). Once the data have been processed, the results shows the variables' grouping in the system of the first two factorial axes, presented in Figure 5.

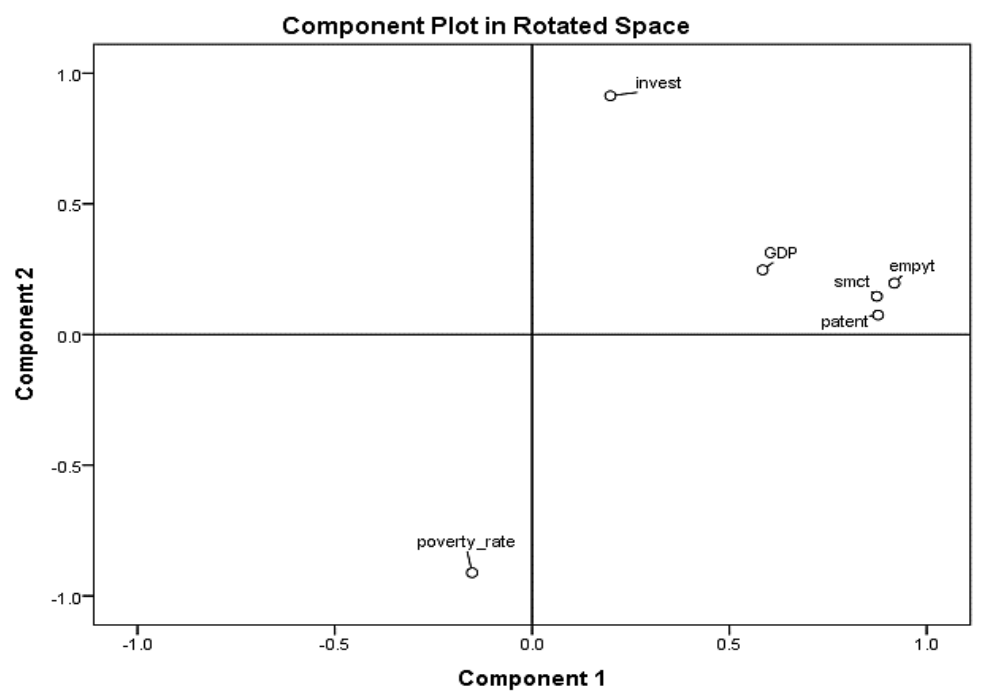

Figure 5. The graphical representation in the system of the first two factorial axes of the used variables (PCA: Rotation method: V arimax with Kaiser Normalization. Component scores) 
Figure 5 represented the visual representation of loadings plotted in a 2 -dimensional space. The plot shows how closely related the variables are to each other. This plot of the component loadings shows that GDP, patent applications, employed ITCs specialists and smart city rankings all load highly and positively on the first component. Investment in $\mathrm{R} \& \mathrm{D}$ has a positive but low loading on the first component, however loads highly on the second. Also, poverty rate loads with a low and negative value on the first component yet highly and negatively on the second.

Table 3. KMO and Bartlett's Test

\begin{tabular}{|l|c|c|}
\hline Kaiser-Meyer-Olkin Measure of Sampling Adequacy. & .706 \\
\hline \multirow{2}{*}{ Bartlett's Test of Sphericity } & Approx. Chi-Square & 237.963 \\
\cline { 2 - 3 } & $\mathrm{df}$ & 15 \\
\cline { 2 - 3 } & Sig. & .000 \\
\hline Source: prepared by the authors & \multicolumn{2}{|c}{} \\
\hline
\end{tabular}

In Table 3 the values for the $\mathrm{KMO}$ test $(\mathrm{KMO}=0.706)$ shows that the included variables explain a significant proportion (over $70 \%$ ) the variance calculated for each category. This is significant (less than .05), indicating that the correlation matrix is significantly different from an identity matrix, in which correlations between variables are all zero.

Due to the ability to create wealth and ideas, governments around the world are investing in the potential of smart cities at an ever increasing rate. Our results show GDP (public and private), R\&D investments, patent applications and employed ITCs specialists are key elements in making a city smarter. The relationships between smart cities and GDP, on one hand and smart cities and R\&D, on the other are bidirectional: a) smart cities contribute to a significant share to country's GDP and it is probable that converting these mega-cities to smart cities may yield a higher contribution to the current GDP and b) $\mathrm{R} \& \mathrm{D}$ results are used to transform cities into smart cities and smart cities have the potential to support innovative growth and R\&D. Several authors confirm that a city become 'smart' if the investments in such infrastructure development are supported [22]. Our findings reveal that for smart cities, GDP and investment in R\&D are both important assets.

A smart city is one system increasingly driven by technically inspired innovation and ICTs merge so widely that they are able to influence not only the nearby environment but also the whole city infrastructure and operation [20, 29]. Moreover, R\&D investment and development of digital technologies have led to a significant increase in the number of patents registered by international organizations. Some of them turn into innovation and contribute to increasing the intelligence of cities, while other are from ICT domain and environmental protection. Nevertheless, their existence contribute to an increase competitiveness which foster economic growth and smart cities development.

The core of the cities success and smartest is their focus on people and their actively involvement in creating smart services that are meant for them and improving their living environment and the overall quality of life [27]. Our analysis shows the existence of a positive relationship between smart cities rankings and the number of people employed in the creative sector (ICT in this case). The core challenges address by the European Commission [7] refers to competitiveness, in particular - research, innovation 
and upgrading the necessary skills to promote the knowledge economy and active labour market to sustain employment, strengthen social cohesion and reduce the risk of poverty. Smart cities solutions are expected to deal with these challenges by increasing the wealth of cities, reduce poverty, maintain employment and offering a safer and optimized environment [28]. In our analysis between poverty rate and smart city there is a negative relationship because a city with a high poverty rate could not be smart. Smartness means access to digital devices, application and services accessible for the citizen with a reasonable standard of living.

Figure 6 shows an analysis of variance approach to evaluate the distances between clusters. By using the Ward's method, cluster membership is assessed by counting the total sum of squared deviations from the mean of a cluster. In group 1 are countries like Estonia, Lithuania, Slovenia, Croatia, Greece, Latvia, Luxemburg, Bulgaria, Slovakia, Denmark, Portugal, Belgium, Czech Republic, Finland, Romania, Hungary and Austria. This group of countries are characterized by a small number of smart cities, ranging from " 0 " to "2", a low number of patent applications (except the case of Austria), a small number of people employed in ITC sector and a lower GDP (except Czech Republic and Denmark). Although Europe 2020 strategy [7] targets an allocation of 3\% of the EU's GDP to be invested in R\&D or innovation, from the analysed sample, only Denmark, and Austria exceed that amount. In this group, half of countries have the poverty rate above the UE-25 average.

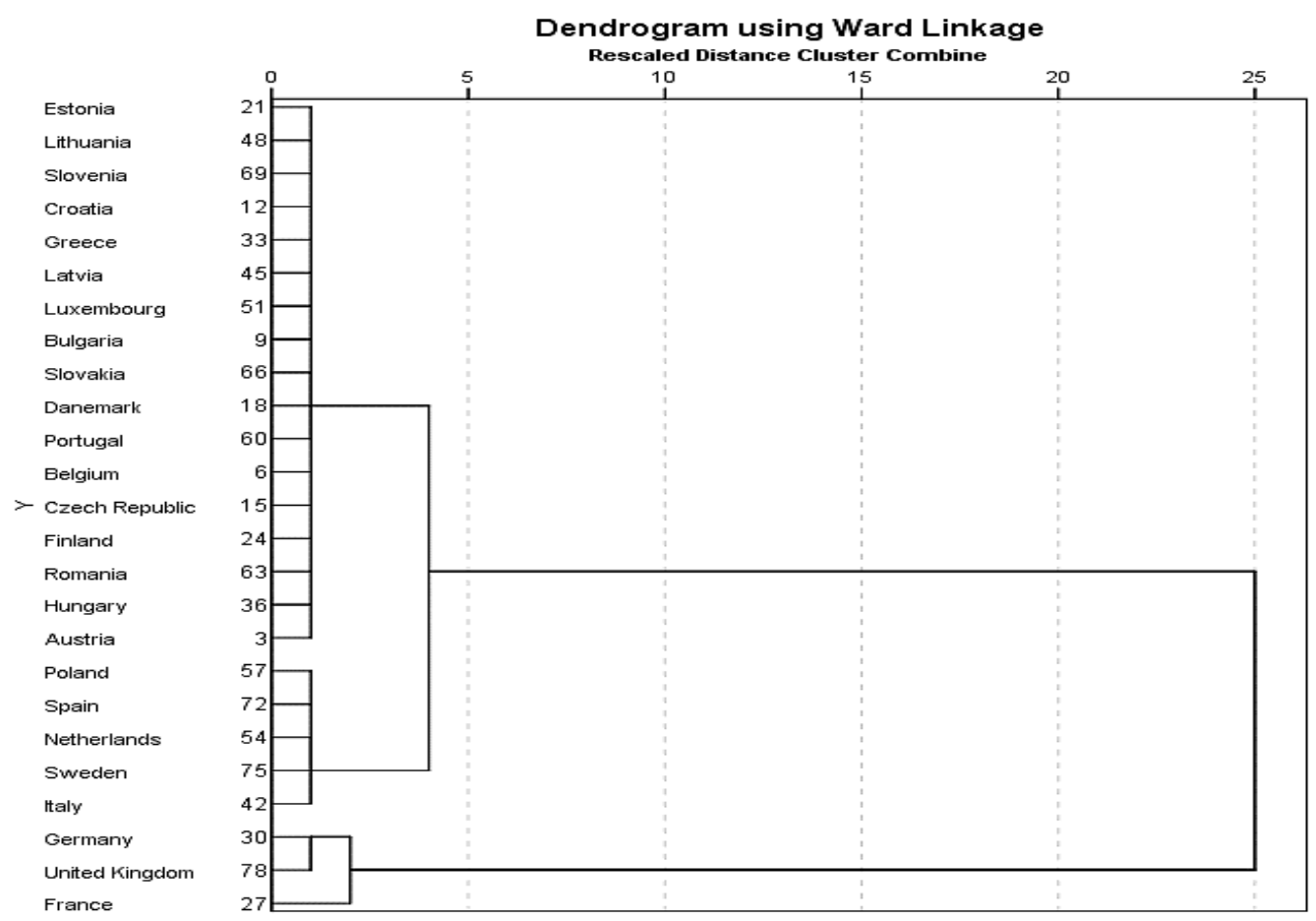

Figure 6. Hierarchical tree diagram, UE-25

Source: Authors' calculations 
In group 2 we have Poland, Spain, Netherlands, Sweden and Italy. The number of smart cities is higher than in group 1, ranging from ' 3 ' in the Netherlands up to ' 11 ' in Spain. In these counties, the highest number of patent applications was 4676 in 2015, which represent more than double of the highest situated country from group 1. Moreover, the GDP level is high so as the number of ICTs employed specialists, which is $77 \%$ more than UE-25 mean. In this group, Sweden allocate more than $3 \%$ of GDP in R\&D or innovation.

In group 3 and 4 we have United Kingdom, Germany and France characterized by the higher number of ITCs specialists, smart cities and patent applications. Also, France has one of the smallest poverty rate from all analysed countries and Germany and France, a value below group average.

If we want to have 3 clusters than 3 and 4 become a cluster. If we want 2, 1 and 2 become a

cluster.

It should be noted that from clusters 1 and 2 no country passes into the cluster with France, Germany and UK whether we have 4, 3 or 2 clusters. This indicates large differences between the three countries and the rest of the sample.

The clusters analysis reveals that countries with higher number of smart cities have higher GDP and more patent applications. Also, the number of people employed in ITC sector is higher than in countries with a low number of smart cities.

\section{Concluding Remarks}

Our findings reveal that significant and positive associations have been found between smart cities R\&D investments, number of patent applications, and employed ICT specialists and GDP. The only negative correlation was with the people at high risk of poverty indicator. The R\&D investments are key asset in implementing the smart city concept as their results are used to transform cities into smart cities and smart cities initiatives have the potential to support innovative growth and R\&D. The existence of patents may not only contribute to increase a country's competitiveness and economic growth but also, they can turn into innovation and increasing the intelligence of cities. The GDP level directly and indirectly influences the implementation of smart cities features as it influences R\&D investments, the possibility of transforming inventions into innovations, the ability to adopt ICTs and the poverty rate. Our results also show a positive relationship between smart cities and the number of people employed in the creative sector (ICT in this case) as they are actively involved in creating smart products and services.

Smart cities are designed to fuel sustainable growth and a high quality of life, including poverty reduction. As our results show there is a negative correlation between smart cities and poverty rate.

Smartness means access to digital devices, application and services accessible for the citizen with a reasonable standard of living. Smart city means also smart people and smart people could fight with poverty which offers a significant advantage for improving living conditions. 


\section{Acknowledgement}

This work was supported by a grant of the "Alexandru Ioan Cuza" University of Iasi, within the Research Grants program, Grant UAIC, code GI-UAIC-2017-03.

\section{References}

Albino, V., Berardi, U., and Dangelico, R.M. (2015). Smart cities: Definitions, dimensions, performance, and initiatives. Journal of Urban Technology, 22(1), 3-21.

Batty, M., Axhausen, K.W., Giannotti, F., Pozdnoukhov, A., Bazzani, A., Wachowicz, M., and Portugali, Y. (2012). Smart cities of the future. The European Physical Journal Special Topics, 214(1), 481-518.

Caragliu, A., Del Bo, C., Nijkamp, P., (2009). Smart cities in Europe. Series Research Memoranda 0048. VU University Amsterdam, Faculty of Economics, Business Administration and Econometrics. Retrieved from https://research.vu.nl/ws/files/2474218/20090048.pdf.

Caragliu, A.; Del Bo, C. and Nijkamp, P. (2009). Smart cities in Europe. Journal of Urban Technology, 18, 65-82.

Dameri, R.P. (2013). Searching for smart city definition: a comprehensive proposal. International Journal of Computers \& Technology, 11(5), 2544-2551.

European Commission (2017). Eurostat Database. Retrieved from http://ec.europa.eu/eurostat/data/database.

European Commission (2010). Europe 2020: A Strategy for smart, sustainable and inclusive growth. Retrieved from http://eur-lex.europa.eu/LexUriServ/LexUriServ.do?uri=COM:2010:2020:FIN:EN:PDF.

Garcia, M. (2017) in Embling, D. (2017). Generation green: smart cities bring new eco-friendly jobs, Retrieved from http://www.remourban.eu/News--Events/News/Generation-Green-Smart-Cities-Bring-NewEco-Friendly-Jobs.kl.

GhaffarianHoseini, A., Dahlan, N.D., Berardi, U., GhaffarianHoseini, A., Makaremi, N. (2013). The essence of future smart houses: From embedding ICT to adapting to sustainability principles. Renewable \& Sustainable Energy Reviews, 24, 593-607.

Gibson, D.V., Kozmetsky, G., Smilor, R.W. (eds.) (1992). The Technopolis Phenomenon: Smart Cities, Fast Systems, Global Networks, Rowman \& Littlefield, New York, USA.

Giffinger, R., Fertner, C., Kramar, H., Kalasek, R., Pichler-Milanović, N., Meijers, E. (2007). Smart Cities: Ranking of European Medium-Sized Cities. Vienna, Austria: Centre of Regional Science (SRF), Vienna University of Technology. Retrieved from www. smart-cities. eu/download/smart_cities_final_report.Pdf.

Hall, R.E., Bowerman, B., Braverman, J., Taylor, J., Todosow, H., Von Wimmersperg, U. (2000). The vision of a smart city (No. BNL--67902; 04042). Brookhaven National Lab., Upton, New York, USA.

Harrison, C., Donnelly, I. (2011). A Theory of Smart Cities. Proceedings of the 25th Annual Meeting of the ISSS2011, 55(1).

Harrison, C., Eckman, B., Hamilton, R., Hartswick, P., Kalagnanam, J., Paraszczak, J., Williams, P. (2010). Foundations for smarter cities. IBM Journal of Research and Development, 54(4), 1-16.

Hurbean, L., Fotache, D., Pavaloaia, D., Dospinescu, O. (2013). Platforme integrate pentru afaceri. ERP. Bucuresti: Economica Publishing House.

Jin, J., Gubbi, A. (2014). An information framework for creating a smart city through internet of things. IEEE Internet of Things (IoT) Journal, 1, 112-121.

Kim, K., Jung, J.K., Choi, J.Y. (2016), Impact of the Smart City Industry on the Korean National Economy: Input-Output Analysis. Sustainability, 8(7), 649.

Kokko, A., Tingvall, P. G., Videnord, J. (2015). The growth effects of R\&D spending in the EU: A metaanalysis. Economics, 9(40), 1.

Komninos, N., Sefertzi, E. (2009). Intelligent cities: R\&D offshoring, Web 2.0 product development and globalization of innovation systems. Second Knowledge Cities Summit, 2009, Shenzhen, China, 5-7 November.

Kourtit, K., Nijkamp, P., Arribas, D. (2012). Smart cities in perspective - a comparative European study by means of self-organizing maps. Innovation: The European journal of social science research, 25(2), 229-246.

Kumar, T. V., Dahiya, B. (2017). Smart Economy in Smart Cities. In Smart Economy in Smart Cities. Springer Singapore, 3-76. 
Lombardi P., Giordano S., Caragliu A., Del Bo C., Deakin M., Nijkamp P., Kourtit K. (2011). An Advanced Triple-Helix Network Model for SmartCities performance. Research Memorandum, 45, 1-22

Manville, C., Cochrane, G., Cave, J., Millard, J., Pederson, J.K., Thaarup, R.K., Liebe, A., Wissner, M., Massink, R., Kotterink, B. (2014). Mapping smart cities in the EU, Retrieved from http://www.europarl.europa.eu/RegData/etudes/etudes/join/2014/507480/IPOLITRE_ET(2014)507480_EN.pdf.

Necula, S. C. (2016). Diversity and Specialization: Public Policies Framework for Innovation, Acta Universitatis Danubius. Economica, 12(1), pp. 64-79.

Pellicer, S., Santa, G., Bleda, A. L., Maestre, R., Jara, A. J. and Skarmeta, A. G. (2013). A global perspective of smart cities: A survey. In Innovative Mobile and Internet Services in Ubiquitous Computing (IMIS). Proceedings of the 2013 Seventh International Conference, IEEE, 439-444.

Popescul, D., Georgescu, M. (2014). Internet of Things-some ethical issues. The USV Annals of Economics and Public Administration, 13(2(18)), 208-214.

Saunders, T., Baeck, P. (2015). Rethinking smart cities from the ground up. Retrieved from https://www.nesta.org.uk/sites/default/files/rethinking_smart_cities_from_the_ground_up_201 5.pdf.

Schaffers H., Komninos N., Pallot M., Trousse B., Nilsson M., Oliveira A. (2011). Smart Cities and the Future Internet: Towards Cooperation Frameworks for Open Innovation. In Domingue J. et al. (eds) The Future Internet. FIA 2011. Lecture Notes in Computer Science, vol 6656. Springer, Berlin, Heidelberg, 431-446.

Šiurytė A., Davidavičienè V. (2016). An Analysis of key factors in developing a Smart City, Bus XXI Century, $8(2), 254-262$.

Soundari, M. H. (2016). Role of ICT Initiatives in Sustainable Progress of Rural Women in India. European Journal of Sustainable Development, $5(1), 39$.

United Nations (2015). World urbanization prospects. The 2014 revision. Retrieved from http://esa.un.org/unpd/wup/Publications/Files/WUP2014-Report.pdf.

Vienna University of Technology (2016). Smart cities. Retrieved from www.smart-cities.eu.

Washburn, D., Sindhu, U., Balaouras, S., Dines, R. A., Hayes, N., Nelson, L. E. (2009). Helping CIOs understand "smart city" initiatives. Growth, 17(2), 1-17.

Wiig, A. (2016). The empty rhetoric of the smart city: from digital inclusion to economic promotion in Philadelphia. Urban Geography, 37(4), 535-553.

World Bank (2017). World Bank Database. Retrieved from http://data.worldbank.org/. 2017. 